\title{
ISLAMIC EDUCATION BASED ON QUANTUM LEARNING: Conceptual and Methodological Perspective
}

\author{
Muhammad Zainal Abidin \\ Universitas Islam Negeri (UIN) Antasari Banjarmasin \\ Jl. A. Yani, KM. 4,5 Banjarmasin, South Kalimantan, Indonesia \\ E-mail: mzabidin@uin-antasari.ac.id
}

\begin{abstract}
Islamic Education Based on Quantum Learning: Conceptual and Methodological Perspective. This article aims to compare quantum learning, a new effective approach to education in the Western world, with the philosophy of Islamic education. There were three foci of the literature studied-the human aspect as both the subject and the object of the education, the learning environment, and the learning methodology. This paper is a study of relevant literature of quantum learning and the philosophy of Islamic education. The result of the comparison shows that conceptually the views of quantum learning as it pertains to human beings as both the subject and the object of the education, the learning environment, and learning methods have many similarities with the spirit of Islamic education. In could be viewed that philosophically, quantum learning has a strong foundation in Islamic eduation. Quantum learning is the concrete form of Islamic education, as developed by the Western perspective of education.
\end{abstract}

Keywords: Islamic education; quantum learning; human being; environment; methodology.

\begin{abstract}
Abstrak: Pendidikan Islam Berbasis Quantum Learning: Tinjauan Konsep dan Metodologi. Artikel ini bermaksud melakukan studi komparatif antara quantum learning, sebagai sebuah pendekatan baru yang efektif bagi pendidikan di dunia barat dengan falsafah pendidikan Islam. Ada tiga aspek yang menjadi fokus kajian yakni pada aspek manusia sebagai subjek dan sekaligus objek pendidikan, lingkungan belajar, dan metode pembelajaran. Tulisan ini merupakan kajian kepustakaan yang melakukan telaahan terhadap berbagai referensi yang relevan dengan isu yang diangkat, yakni quantum learning dan filsafat pendidikan Islam. Hasil kajian ini menunjukkan bahwa secara konseptual pandangan-pandangan quntum learning tentang manusia sebagai subyek dan obyek pendidikan, lingkungan belajar dan metodologi pembelajarannya memiliki kemiripan dengan spirit pendidikan Islam. Dengan kata lain, bahwa quantum learning secara filosofis memiliki dasar yang kuat dilihat dari kacamata filsafat pendidikan Islam dan quantum learning merupakan bentuk konkret dari filsafat pendidikan Islam yang dikembangkan dengan baik oleh dunia pendidikan di Barat.
\end{abstract}

Kata kunci: pendidikan Islam; quantum learning; manusia; lingkungan; metodologi.

\section{Introduction}

The world of education, continues to evolve with changing times-enlivened by various innovations in methods and approaches to learning. One such new innovation is the theory of quantum learning. This approach seeks to optimally utilize the basic potential or ability possessed by the learner. The utilization of human potential is carried out in various ways or techniques that involve the whole person-the intellect, the physical, and the emotional.

Quantum learning departs from the basic philosophy that underlies all of its curriculum. The basic philosophy in question is the philosophy of human existence which naturally has potential that can be developed. Humans when born, are not empty, but instead contain the power of action. To support this basic philosophy, in quantum learning a supportive environment is prepared so that all students feel important, safe and comfortable. It starts with the actual physical environment, which is enhanced by plants, art and music. Emotional environment also gets no less important attention. Guides in quantum learning are 
experts who form the fabric of understanding. ${ }^{1}$

That is the explanation of Bobbi DePorter and Mike Hernacki as the Founder of Quantum Learning in their populer book, Quantum Learning: unleash the genius within you, which later became the inspiration of many schools or educational institution in Indonesia to implement various approaches used in quantum learning or quantum teaching as reported by Muhajir, ${ }^{2}$ Suryani, ${ }^{3}$ Turnip and Panjaitan, ${ }^{4}$ Bahaddin and Yusuf, ${ }^{5}$ Bratasari, ${ }^{6}$ Darkasyi, 7 Widyastanto, ${ }^{8}$ and still there are many other researchers who acknowledge the efectivity of quantum learning approaches and strategies.

Inspired by the success of the quantum learning's book in 1993, they are some other works of Bobbi DePorter and Mike Hernacki used the term quantum such as quantum business (1997), ${ }^{9}$ quantum learning for bussiness (1998), ${ }^{10}$

\footnotetext{
'Bobbi DePorter and Mike Hernacki, Quantum learning: Membiasakan Belajar Nyaman dan Menyenangkan, trans. Alwiyah Abdurrahman (Bandung: Penerbit Kaifa, 1999), p. 8.

${ }^{2}$ Muhammad Muhajir, "Model Pembelajaran Quantum Teaching Dalam Pembelajaran Pendidikan Agama Islam di SDIT Buah Hati Sintang," Ulul Al Bab: Islamic Education Journal Vol. 1, No. 2, 2014, p. 23.

3 Nunuk Suryani, "Improvement of Students History Learning Competence through Quantum Learning Model at Senior High School in Karanganyar Regency, Solo, Central Java Province, Indonesia," Journal of Education and Practice Vol. 4, No. 14,2013 , p. 55-63.

4 Jaidun Turnip and Keysar Panjaitan, "Penerapan Model Quantum Learning Untuk Meningkatkan Hasil Belajar Autocad Teknik Gambar Bangunan," Jurnal Teknologi Pendidikan (JTP) Vol. 7, No. 2, 2014, http://jurnal.unimed.ac.id/2012/index.php/ jtp/article/view/1856, accessed July 7, 2018.

${ }^{5}$ Rochmadani Bratasari, "Eksperimen Pendekatan Quantum Teaching Dan Quantum Learning Terhadap Pemahaman Konsep Pada Anak Subnormal" (Universitas Muhammadiyah Surakarta, 2009), http://eprints.ums.ac.id/4695, pdf, accessed July 6, 2018.

${ }^{6}$ Rochmadani Bratasari, "Eksperimen Pendekatan Quantum"...., http://eprints.ums.ac.id/4695, pdf, accessed July 6, 2018.

7 Muhammad Darkasyi, Rahmah Johar, and Anizar Ahmad, "Peningkatan Kemampuan Komunikasi Matematis Dan Motivasi Siswa Dengan Pembelajaran Pendekatan Quantum Learning Pada Siswa SMP Negeri 5 Lhokseumawe," Jurnal Didaktik Matematika, Vol. 1, No. 1, 2014.

${ }^{8}$ Hermawan Widyastantyo and others, Penerapan Metode Quantum Learning Untuk Meningkatkan Hasil Belajar Mata Pelajaran IPA (SAINS) Bagi Siswa Kelas V SD Negeri Kebonsari Kabupaten Temanggung, (Universitas Negeri Semarang, 2007).

${ }^{9}$ Bobbi DePorter and Mike Hernacki, Quantum Business: Achieving Success through Quantum Learning (New York: Dell, 1997).
}

${ }^{10}$ Bobbi DePorter and Mike Hernacki, Quantum Learning for Business: How to Be More Confident, Effective and Successful at Work (London: Piatkus, 1998). quantum pathways (2000), ${ }^{11}$ quantum thinking (2000),,$^{12}$ quantum writing (2000), ${ }^{13}$ quantum reading (2000), ${ }^{14}$ quantum notes (2000), ${ }^{15}$ quantum memory (2000), ${ }^{16}$ quantum writer (2007), ${ }^{17}$ and quantum memorizer (2007). ${ }^{18}$ All of books were best seller and became the success story of the writers.

As an approach developed in the world of Western education, the big question for quantum learning is how the compatibility this method or approach with Islamic teaching. Especially for those who have a priori views or negative perspective on the West as a source of "problems" for Muslims, who have a different philosophy of life from Islam, and they want to uproot Muslims from the roots of their Islamic tradition. ${ }^{19}$

To answer the above question, this article intends to elaborate on the philosophical basis of quantum learning and compare it with the philosophy of Islamic education. This comparison is simply to ascertain whether the quantum learning corresponds or even contradicts the philosophy of Islamic education, so that when there are those who adopt and apply this method, there is nothing more to do with the original source of the quantum learning approach.

There are three aspects of concern in this paper, namely: the views in quantum learning about humans as the subject and object of

${ }^{11}$ Bobbi DePorter and Mike Hernacki, Quantum Pathways: Discovering Your Personal Learning Style (Oceanside, Calif.: Learning Forum Publications, 2000).

${ }^{12}$ Bobbi DePorter and Mike Hernacki, Quantum Thinking: Creative Thinking, Planning and Problem-Solving (Oceanside, Calif.: Learning Forum Publications, 2000).

${ }^{13}$ Bobbi DePorter and Mike Hernacki, Quantum Writing: How to Write like a Pro (Oceanside, Calif.: Learning Forum Publications, 2000).

${ }^{14}$ Bobbi DePorter, Quantum Reading: The Power to Read Your Best (Oceanside, Calif.: Learning Forum Pub., 2000).

15 Bobbi DePorter and Mike Hernacki, Quantum Notes: Whole-Brain Approaches to Note-Taking (Oceanside, Calif.: Learning Forum Publns., 2000).

${ }^{16}$ Bobbi DePorter and Mike Hernacki, Quantum Memory: Working Magic with Your Memory (Oceanside, Calif.: Learning Forum Publications, 2000).

${ }_{17}$ Bobbi DePorter and Mike Hernacki, Quantum Writer: Write Easily, Less Stress, Better Results (Oceanside, Calif.: Learning Forum Publns., 2007).

${ }^{18}$ Bobbi DePorter, Quantum Memorizer: Remember Anything, Anytime (Oceanside, Calif.: Learning Forum Publications, 2007).

19 Muhammad Zainal Abidin, "Filsafat Ilmu-IImu Keislaman Integralistik: Studi Pemikiran Kuntowijoyo," Jurnal IImu Ushuluddin, Vol. 13, No. 2, 2014, pp. 119-134. 
education, the learning environment, and the methodology used in the learning process. This is then compared to Islamic education perspective.

Initial assumptions that are believed by the author, there is a match between the philosophy in quantum learning and the philosophy of Islamic education. This is because quantum learning from the beginning states that it is based on convergence theory that intends to marry endogenous factors (talent brought from birth, nativism) and exogenous factors (external influences, empiricism) as two factors that go together in the formation of students' future. ${ }^{20}$

In Islamic teachings, there is one very popular hadith that is relevant to the convergence theory, namely the Hadith of the Messenger of Allah which reads: "Every person is born carrying nature (fitrah), his parents made him a Jew, Christian, or Majusi." (H.R. Bukhari and Muslim). This hadith emphasizes that the nature (fitrah) that was brought from birth to the child is very much influenced by the environment. Fitrah itself will not develop without being affected by environmental conditions. External factors join fitrah, its nature depends on the extent to which external interactions with fitrah play a role. ${ }^{21}$

Therefore, one of the principles of the Islamic education system is the necessity to use a comprehensive method of approach to humans: covering the physical-spiritual dimensions and all aspects of life, both those that can be reached by reason and those that are only believed through the heart, not only outwardly, but also inward. And the method of holistic approach (comprehensive) one of which has been applied in quantum learning.

\section{Conceptualization of Quantum Learning and Islamic Education 1. Quantum Learning}

Etymologically quantum means jumps. That is to say that humans turned out to have an extraordinary ability to jump, to rise above the

20 Mastuhu, Memberdayakan Sistem Pendidikan Islam: Strategi Budaya Menuju Masyarakat Akademik (Jakarta: Logos, 1999), p. 27.

${ }^{21}$ Saryono Saryono, "Konsep Fitrah dalam Perspektif Islam," Medina-Te : Jurnal Studi Islam Vol. 12, No. 2, 2016. pp. 161-74. predicted ability. Quantum learning shows that human potential to develop (potential for growth) is almost unlimited. ${ }^{22}$

Quantum learning is rooted in Dr. George Lozanov, a Bulgarian educator who experimented with what he called "suggestology" or "suggestopedia". ${ }^{23}$ The principle is that suggestions can and certainly affect the outcome of the learning situation and any detail gives positive or negative suggestions ${ }^{24}$

Learning methods applied in quantum learning are generally called "accelerative learning" or learning acceleration which is defined as allowing students to learn at impressive speeds, with normal effort accompanied by excitement. ${ }^{25}$

Quantum learning covers important aspects of a Neuro-Linguistic Program (NLP), which is a study of how the brain regulates information. ${ }^{26}$ This program examines the relationship between language and behavior and can be used to achieve the fabric of understanding between students and teachers. ${ }^{27}$

In the end, it can be explained that quantum learning is a combination of suggestology, learning acceleration techniques, and NLP with certain theories, beliefs, and other methods. This includes key concepts from various theories and other learning strategies, such as: right / left brain theory, triune brain theory (3 in 1), choice of modalities (visual, auditory, and kinesthetic), multiple intelligence theories, holistic education (thorough), learning based on experience, learning with symbols (metaphoric learning) and simulation / games..$^{28}$

${ }^{22}$ Jalaluddin Rakhmat, Catatan Kang Jalal: Visi Media, Politik, dan Pendidikan (Bandung: Remaja Rosdakarya, 1997), p. 351.

${ }^{23}$ Donald H Schuster and DesMoines, Society for Suggestive - Accelerative Learning and Teaching, Suggestive, Accelerative Learning and Teaching: A Manual of Classroom Procedures Based on the Lozanov Method. (Charles Gritton, 1976).

${ }^{24}$ DePorter and Hernacki, Quantum learning..., p. 14.

25 Donald H Schuster and Charles E Gritton, SALT: Suggestive Accelerative Learning Techniques: Theory and Applications (Ames, lowa: D. Schuster, 1985).

${ }^{26}$ Dianne Lowther, Introducing Neurolinguistic Programming for Work: A Practical Guide. (New York: Icon Books, 2013).

${ }^{27}$ Jane Vella, "Quantum Learning: Teaching as Dialogue," New Directions for Adult and Continuing Education 2002, No. 93, 2002, pp. 73-84.

${ }^{28}$ DePorter and Hernacki, Quantum learning..., p. 16. 
Departing from all of the above and seeing the effectiveness and efficiency of this method, then quantum learning is then defined as interactions that convert energy into light. All life is energy. A well-known formula in quantum physics is mass times the speed of light squared equal to energy.

\section{Islamic Education}

In terms of language, education can be defined as actions (things, ways and so on) educating; and means also the science of educating, or maintaining (exercises and so on) body, mind and so on. Education - which is also attached to Islam-has been defined differently by different people according to their opinions. But all these opinions met in view, that "Education is a process by which a nation prepares its young generation to carry out life and to fulfill the purpose of life effectively and efficiently.

Understanding education with all its totality in the context of Islam is inherent in the connotation of the terms "tarbiyyah", "ta'lîm" and "ta'dîb" which must be understood together. ${ }^{29}$ The three terms contain very deep meanings concerning humans and society and the environment whose relationship with God is interrelated. Literally, tarbiyyah means 'educate', ${ }^{30}$ ta'lim means 'knowledgeable' and ta'dib derived from the word 'adaba' means 'moral'. These terms comprehensively are concerning the multilateral relationship of human and their society; human and environment; society and environment; and in relation to Allah. ${ }^{31}$

${ }^{29}$ Muhammad Naqîb-al-'Attâs, The Concept of Education in Islam a Framework for an Islamic Philosophy of Education (Kuala Lumpur: International Institute of Islamic Thought and Civilization, 1999).

30 The concept Muhammad Naqib al-'Attas (1996) on tarbiyah is only one sub-system of ta'dib. Hence, tarbiyah concepts and differences among the study groups encourage writer to study it from the perspective of semantic study. See Dedeng Rosidin, "Al-Tarbiyah Meaning in Al-Qur'an and Its Implication in Learning and Commentary Education Major in Arabic FPBS UPI," EDUCARE Vol. 4, No. 1, 2011, http://www. journals.mindamas.com/index.php/educare/article/view/243, accessed July 10, 2018.

${ }^{31}$ Mohamad Johdi Salleh, "The Integrated Islamic Education: Principles and Needs for Thematic Approaches," in An Integrated Islamic Education: Need for Thematic Approaches, Singapore Islamic Education System (SIES) Seminar, Wisma MUIS, Singapore, On Vol. 14, 2009.
Historically, Islamic education can refer to efforts by the Muslim community to educate its own, to pass along the heritage of Islamic knowledge, first and foremost through its primary sources, the Quran and the Sunnah. This education of Muslims might take place in mosques, schools or universities, and other organizations established by Muslims over the centuries. ${ }^{32}$

The concept of education in Islam is a conscious guidance or leadership by the educator on the physical and spiritual development of the educated towards the formation of the main personality. The Islamic education also is a complete human education; mind and heart, spiritually and physically; character and skills. Because Islamic education prepares people for life and faces society with all its good and evil, sweet and bitter. So, it be concluded that there were differences between Islamic and liberal ways of understanding education. ${ }^{33}$

The Islamic education here aims to create a balanced growth and total human personality through spiritual practice, intellect, rational self, feeling and sensitivity of the human body. Education includes various dimensions: body, mind, feeling, will, and all elements of the human psyche and its talents and abilities. Education is an effort to develop individual talents and abilities, so that psychological potentials can be perfectly actualized. The concept of education in Islam must take into consideration of all the dimensions. No matter which one of the above concepts is preferable to scholars, it should not be used as a pretext for controversy and intellectual acrimony among scholars, because what does it matter is not the concept, but the practice, methodology and its objectives. Education occupies a significant position in Islamic civilization. ${ }^{34}$

${ }^{32}$ Susan L. Douglass and Munir A. Shaikh, "Defining Islamic Education: Differentiation and Applications," Current Issues in Comparative Education Vol. 7, No. 1, 2004, pp. 5-18.

33 Mark Halstead, "An Islamic Concept of Education," Comparative Education, Vol. 40, No. 4, 2004, pp. 517-29, https:// doi.org/10.1080/0305006042000284510, accessed July 10, 2018.

34 See also Raudlotul Firdaus Fatah Yasin and Mohd Shah Jani, "Islamic Education: The Philosophy, Aim, and Main Features" (conference, 2013), http://irep.iium.edu.my/34152/, accessed July 25, 2018. 
From some of the above definitions, it can be concluded that education is an effort that is done consciously from someone to someone who aims to form a complete personality that includes aspects of physical, spiritual and totality of the human personality. The above understanding is in harmony with Islamic education which is the inheritance of Islamic values that lead to the balance and harmony of the development of human life both physically and spiritually towards the formation of a perfect personality.

The conceptualization of Islamic education in more depth can be seen from the opinions of educational leaders and experts: For example, Hasan Langgulung defines Islamic education as a spiritual, moral, intellectual, and social process that seeks to guide people and give them values, principles and an ideal example in life that aims to prepare for the life of the world and the hereafter. From the context of philosophy, Islamic Philosophy is based on divine revelation, which is the Quran and the Sunnah. According to Hassan Langgulung, the basis of Islamic philosophy are the believe in God (Allah), the believe in God's devotees, the believe in divine revelation that had been gave to the prophets, the believe that human has a potency within the development of morality and spirituality, the believe that each individual is responsible for his action, the belief in life and life after death, and also the belief on universal similarity among the Muslims. Based on these aspects, a balance and holistic individual is able to be produced through the appreciation towards Islamic Philosophy of Education. ${ }^{35}$

So, we can understand then that the meaning of education in general as stated above, emphasizes that Islamic education is physical and spiritual guidance based on Islamic laws towards the formation of a full personality according to Islamic measures. With a somewhat different expression Naquib al-Attas states that Islamic education is an attempt to form humans who occupy their place proportionally in accordance with the composition

35 Aminuddin Hassan et al., "The Role of Islamic Philosophy of Education in Aspiring Holistic Learning," Procedia-Social and Behavioral Sciences Vol. 5, 2010, pp. 2113-2118. of science and technology under their control. ${ }^{36}$ For Abdurrahman an Nahlawi, 37 Islamic education can form a person who embodies divine justice in the human community and is able to utilize natural potential with fair use.

Regarding what is to be achieved in Islamic education, the first international conference on Islamic education in 1977 has formulated that the aim of Islamic education is to achieve a comprehensive growth of human personality in a balanced manner through the exercise of the soul, intellect, rational human self, feelings and senses..$^{38}$ Therefore education must include human growth in all its aspects: spiritual, intellectual, imaginative, physical, scientific, linguistic, both individually and collectively, and encourage all these specimens towards goodness and perfection. The ultimate goal of Muslim education lies in the realization of perfect submission to God both personally, community and all humanity. ${ }^{39}$

From some understanding of Islamic education described above, it can be understood that Islamic education is an educational process which is a series of efforts to guide, direct the potential of human life, in the form of basic abilities (fitrah) and learning abilities, so that there is a change in the life of his personality as individual beings and creatures social. The process is always based on the ideal values of Islam which give birth to shariah norms and akhlakul karîmah to prepare for the goodness (hasanah) in this world and the hereafter.

${ }^{36}$ Naqîb-al-'Attâs, The Concept of Education in Islam a Framework for an Islamic Philosophy of Education, 35.; See also Abdul Ghoni, "Pemikiran Pendidikan Naquib Al-Attas dalam Pendidikan Islam Kontemporer," Jurnal Lentera: Kajian Keagamaan, Keilmuan dan Teknologi Vol. 3, No. 1, March 30, 2017, pp. 196-215.

${ }_{37}$ Abdurrahman An Nahlawi, Pendidikan Islam di Rumah, Sekolah dan Masyarakat (Gema Insani, 1995), 27.; Musmualim and Muhammad Miftah, "Pendidikan Islam di Keluarga Dalam Perspektif Demokrasi (Studi Pemikiran Hasan Langgulung dan Abdurrahman an Nahlawi)," JURNAL PENELITIAN, Vol. 10, No. 2 (December 29, 2016), https://doi.org/10.21043/jupe.v10i2.1781, accessed July 25, 2018.

${ }^{38}$ See M. Zainal Abidin, "Islam Dan IImu Pengetahuan: Diskursus Pemikiran Muslim Kontemporer," ULUMUNA, Vol. 10, No. 2, 2006, pp. 391-410.

39 Halstead, "An Islamic Concept of Education... https://doi. org/10.1080/0305006042000284510, accessed July 10, 2018” 


\section{Quantum Learning Vis-a-Vis Islamic Education}

Islamic education is a very systemic building, when compared with quantum learning which is only a method or approach in the world of education, it looks unbalanced. But departing from the success of quantum learning as an approach in the world of education, it would not be wrong if an in-depth study was done and looked at it from the perspective of Islamic education, so that there was mutual take and give between the two.

There are three conceptions of quantum learning to be seen from the point of view of Islamic education. First, namely on his view of human beings as subjects and objects of education, second, namely in his view of the environment that supports the learning process and the third, namely the learning methodology applied there. The three views will be explained as below:

\section{Views on Human beings}

The position of human being as it is known is very decisive in an educational process. Any discussion about education must first strip human beings. Because humans are both subjects and objects of education.

Quantum learning as an approach in the world of education cannot be separated from this too. Every human according to quantum learning has the same potential. The differences are more about how humans use their brains ${ }^{40}$. Apart from the real differences in intelligence and the level of success among our people, according to Bobbi DePorter, "the nervous system we have is the same. The physiology of your brain is very similar to other people, even with brilliant thinkers like Einstein and Da Vinci. ${ }^{41}$

The idea that everyone has the same potential, has a positive impact on the development of students. Everyone then realizes that he has a tremendous opportunity. This kind of understanding allows one to imitate others and use that person as a model by arranging

\footnotetext{
$4^{\circ 0}$ DePorter and Hernacki, Quantum learning..., p. 40.

${ }^{41}$ DePorter and Hernacki, Quantum learning..., p. 40.
}

thinking patterns and bodies like him. In quantum learning, the whole person is important, both mind, physical and emotional / personal. High self-respect is an important material in shaping healthy and happy students. ${ }^{42}$

Viewed from the perspective of Islamic education, the view that humans have potential that can be developed is very relevant. In fact, it is one of the main ideas of Islamic education. Man, as expressed by Quraish Shihab, ${ }^{43}$ is a being who is created from the ground (physical) and the Divine Spirit (reason and spirit), he is also given the gift of potential, with which he then becomes a creature capable of composing concepts, creating, develop, and express ideas and implement them. According to him, this potential is evidence that makes angels willing to prostrate to Adam.

A word that is commensurate with this potential in the concept of Islamic education is fithrah. ${ }^{44}$ Literally it means creation, causing something to exist for the first time, and the natural general structure/characteristic with which a child is created in the mother's womb. According to Quraish Shihab that "human nature is its occurrence from the beginning or innate from birth". Islamic education, as well as those applied in quantum learning, seeks to make maximum use of the potential possessed by humans. In the first International Conference on Islamic Education in 1977 had formulated the goals of Islamic education as "an effort to achieve a comprehensive growth of human personality in a balanced manner". 45

The objectives formulated at the conference were also agreed upon by many Islamic education experts. Ali Ashraf, for example, stated that "education should aim at creating balanced growth and a total human personality". Here,

${ }^{42}$ DePorter and Hernacki, Quantum learning..., p. 8.

${ }_{43}$ M. Quraish Shihab, Wawasan Al-Quran: Tafsir Tematik atas Pelbagai Persoalan Umat (Mizan Pustaka, 1996), p. 283.

44 Mohammad Muchlis Solichin, "Fitrah: Konsep Dan Pengembangannya Dalam Pendidikan Islam," TADRIS: Jurnal Pendidikan Islam Vol. 2, No. 2, 2007, https://doi.org/10.19105/jpi. v2i2.219, accessed July 6, 2018.

${ }^{45}$ Ghulam Nabi Saqeb, "Some Reflections on Islamization of Education since 1977 Makkah Conference: Accomplishments, Failures and Tasks Ahead," Intellectual Discourse Vol. 8, No. 1, June 1, 2000, https://doaj.org, accessed May 11, 2018. 
With a slightly different expression, according to Muhammad Amin that "education covers various dimensions: body, mind, feeling, will, and all elements of the human psyche and its talents and abilities". Education according to him is an effort to develop individual talents and abilities, so that the psychological potentials can be perfectly actualized. These potentials are actually valuable assets in human beings. ${ }^{46}$

In the concept of Islam, with the complete development of all human potential it is hoped that he (human beings) can carry out his service function as a caliph on earth. On the basis of this understanding, the aim of the education of the Quran (Islam) was to foster humans personally and in groups so as to be able to carry out their functions as servants and caliphs, in order to build this world in accordance with the established concept God. Or in other words shorter and often used by the Quran, to be devoted to Him. ${ }^{47}$ However, taqwa itself according to Fazlur Rahman ${ }^{48}$ is the highest level that shows a truly intact and integral human personality; this is a kind of stability that occurs after all elements of positive traits are absorbed into human beings.

If in quantum learning, all existing curricula are a combination of three elements: academic skills, physical achievement, and life skills. As well as the entire human person is considered important, both intellectually, physically and emotionally / personally, then in Islam it is also developed with serious attention, even more than that. In an Islamic perspective, the people who are fostered are beings who have material (physical) and immaterial (mind and soul) elements. The formation of his mind produces knowledge. His soul formation results in purity/ ethics, while his physical coaching produces skills. 49

${ }^{46}$ Mahyuddin Barni, "Dasar dan Tujuan Pendidikan Islam," Al-Banjari : Jurnal Ilmiah Ilmu-llmu Keislaman Vol. 7, No. 1, May 28, 2008, https://doi.org/10.18592/al-banjari.v7i1.943, accessed May 7, 2018.

${ }^{47}$ As'aril Muhajir, "Tujuan Pendidikan Dalam Perspektif AlQur'an," Al-Tahrir Vol. 11, No. 2, November 1, 2011, pp. 237-60.

${ }^{48}$ Fazlur Rahman, Tema Pokok Al Qur'an, trans. Anas Mahyuddin and Ammar Haryono (Bandung: Pustaka, 1996), p. 43.

49 Anwar Mujahidin and Zamzam Farrihatul Khoiriyah, “Konsep Pendidikan Prenatal Dalam Perspektif Tafsir Al-
Islam is not only prominent in paying attention to all aspects of human existence and does not neglect the slightest variety of powers contained therein. But the most prominent thing is that Islam is in line with nature and things that are further from it. Human existence referred to here is physical or spiritual or physical, reason and spiritual. If reason is considered as an independent element outside the body and spirit. Between one and the other cannot be separated. Humans are not only composed of bodies that stand alone without connection with reason and spirit. Humans are not only reason that stands alone, has nothing to do with the body and spirit and not only spirits without any connection with reason or body. Humans are a complete form of elements that are rigid.

Departing from the explanation above, it appears that the quantum learning view of humans as subjects and objects of education, when viewed from the perspective of Islamic education is not much different. The differences are more in the position of humans in Islamic education that is very comprehensive, including the physical and spiritual aspects and reason. While in human quantum learning is more seen from the physical and emotional (psychological) point of view that supports the learning process.

Potential which is the natural nature of humans in quantum learning, in essence more on physiological things, in the sense that human capacity to develop each person is equal. Slightly different from the potential or fitrah in Islamic education, which also includes the potential (character) for religion.

\section{View on Environment}

In the concept of quantum learning, all curriculum in harmony is a combination of three elements: academic skills, physical achievement, and life skills. Underlying this curriculum according to Bobbi DePorter an dmice Hernacki ${ }^{50}$ is basic philosophy, with the

Mishbâh Karya M. Quraish Shihab," Ta'allum: Jurnal Pendidikan Islam Vol. 6, No. 1, June 1, 2018, pp. 121-50.

50 DePorter and Hernacki, Quantum learning..., p. 8. 
belief that in learning to be effective it must be able and enjoyable. Learning in the concept of quantum learning is a lifelong activity that can be done with fun and success.

To support this philosophy, quantum learning is then prepared in an environment that can make all students feel important, safe and comfortable. It starts with a physical environment that is enhanced by plants, art and music. The room is also formatted in such a way that it feels right for optimal learning activities. ${ }^{51}$

Emotional environment also gets no less serious attention. Guides in quantum learning are the experts who make up the fabric of understanding, and after they establish an emotionally secure area, they confront students in the challenges they get success time after time. ${ }^{52}$

In the perspective of Islamic education, the environment is very influential on the potency (inheritance) possessed by a student. To develop its basic potential/ability, humans need help from others to guide, encourage, direct so that these various potentials can grow and develop naturally and optimally, so that later their lives can be efficient and effective.

In one hadith the Prophet Muhammad stated that "every person is born in a state of nature; it was his father-mother who made him Jewish, Christian, or Majusi "(H.R. Bukahri and Muslim). According to this hadith, humans are born carrying abilities; ability is what is called innate. The fitrah referred to in the hadith is potential. Potential is ability; so the nature that is meant here is innate. The parents in this hadith are the environment as meant by education experts. Both of them, according to this hadith, determine the development of a person.

In a broad sense the environment includes climate and geography, place of residence, customs, knowledge, education and nature. In other words, the environment is everything that appears and exists in an ever-evolving realm of life. He is all that exists, both human and manmade objects.

\footnotetext{
${ }^{51}$ DePorter and Hernacki, Quantum learning..., p. 8.
}

${ }^{52}$ DePorter and Hernacki, Quantum learning..., p. 8.
A significant difference between quantum learning and Islamic education in viewing the environment, perhaps lies in the meaning of the environment itself. In quantum learning, the environment referred to as expressed by Bobbi Deporter is "an environment that supports the learning process", which includes physical and emotional environments. ${ }^{53}$ So it is more micro (narrow) and limited, in contrast to Islamic education that sees an environment that supports the development of human potential more macro. But philosophically in the perspective of Islamic education, the view of quantum learning is the same, that for the development of human potential optimally needs support from the surrounding environment.

\section{Teaching Methodology}

In quantum learning there is a philosophy that is held firmly, that learning is a lifelong activity that can be done pleasantly and successfully. The curriculum applied there is a combination of academic skills, physical achievement, and life skills with optimization on reason, physical and emotional/personal. ${ }^{54}$

Quantum learning is basically rooted in the efforts of Georgi Lozanov, who experimented with what he called the suggestology or suggestopedia. In principle Lozanov with suggestology suggests that every detail means. Definitive suggestions and can affect the results of learning situations. Either positive or negative suggestions. Some of the techniques he uses to provide positive suggestions are to comfortably place students, put background music in the classroom, increase individual participation, use posters to give a big impression while highlighting information and providing teachers who are well trained in the art of suggestive teaching. ${ }^{55}$

In addition to suggestology, quantum learning also bases itself on accelerated learning. In essence, it is defined as allowing students to learn at impressive speeds, with normal effort,

53 Bobbi DePorter Singer-Nourie Mark Reardon, Sarah, Quantum Teaching: Mempraktikkan Quantum Learning Di RuangRuang Kelas (Kaifa, 2000), p. 14.

54 DePorter and Hernacki, Quantum learning..., p. 8.

55 DePorter and Hernacki, Quantum learning..., p. 14. 
coupled with excitement. The method applied in accelerating learning brings together elements that at first glance seem to have nothing in common: entertainment, play, color, positive thinking, physical fitness, and emotional health, but all these elements work together to produce effective learning experiences. ${ }^{56}$

Quantum learning also includes important aspects of a Neuro-Linguistic Program (NLP), which is a study of how the brain regulates information. This program examines the relationship between language and behavior and can be used to create a fabric of understanding between students and teachers. Educators with NLP knowledge know how to use positive language to improve positive actions, which are important factors to stimulate the most effective brain function.

Departing from the curriculum applied in quantum learning is a combination of academic skills, physical achievement, and skills in life by optimizing on reason, physical and emotional / personal, in its implementation in the field, the method applied to achieve all that is by creating an environment that support, both physical and emotional.

In the physical environment, this is done by creating a positive, safe and supportive, relaxed, exploratory and encouraging condition. In a comfortable atmosphere, enough lighting, pleasing to the eye and music. While in the emotional environment, what is built is a fabric of understanding, both between mentors (teachers) and their students, as well as between students. It was stated by Bobbi DePorter:

... in our program, the mentors are experts who form the fabric of understanding, and after they establish an emotionally secure area, they confront students in the challenges that they get success from time to time...57

...when students enter this bright, comfortable and inviting physical environment on the opening day, everyone is greeted privately by the team leader..... ${ }^{8}$

\footnotetext{
${ }^{56}$ DePorter and Hernacki, Quantum learning..., p. 14.

${ }^{57}$ Singer-Nourie, Quantum Teaching..., p. 8.

${ }^{58}$ DePorter and Hernacki, Quantum learning..., p. 66.
}

... through the use of communication exercises and other group activities, they get to know their group members, they know each other well. We make them feel comfortable with themselves as individuals and as group members.... ${ }^{59}$

In this safe environment, where understanding relationships have been created, both between mentors and students and between fellow students, they generally open themselves to expand their areas of comfort and try new things - and that is the ideal state of mind for optimal learning. In quantum learning, only after having produced this kind of mind state, new academic skills are introduced which help students become better at school. ${ }^{60}$

In making breakthroughs in learning, quantum learning carried out some paradigm shifts in the "inadequate" mindset, by providing physical challenges that were used as symbols for learning breakthroughs. ${ }^{61}$

In the perspective of Islamic education the concept of quantum learning which holds a strong philosophy that learning is a lifelong activity that can be done pleasantly and successfully with a methodology based on a curriculum which is a combination of academic skills, physical achievement, and skills in life, is very relevant to educational philosophy all life that becomes a foothold in Islamic education.

The nature of the education of the Quran (Islam) is "rabbaniy", based on the first verse in the first revelation. The person who carries out is also called "rabbaniy" whose characteristics are described by the Quran, among others: teaching the book of God, both written (the Quran), and the unwritten (the universe), and learning it continuously (Q.S. Âli 'Imran [3]: 79).

The range that must be learned, which is so broad and comprehensive, cannot be achieved perfectly by someone. But he must try his best to get what he can achieve. Therefore, he is required to continue learning. On this basis, it is very popular what is considered by some as the Prophet's Hadith. That reads: "Look for

\footnotetext{
59 DePorter and Hernacki, Quantum learning..., p. 68.

${ }^{60}$ DePorter and Hernacki, Quantum learning..., p. 68.

${ }^{61}$ DePorter and Hernacki, Quantum learning..., p. 10.
} 
knowledge from the cradle to the burrow of the lahad!" Regardless of whether or not the statement was true to the Prophet, what was clear was that it was in line with the Quranic concept of having to study and obtain lifelong education. ${ }^{62}$

Islamic methodology in conducting education is to take a comprehensive approach to human form, so that no one is left behind or neglected at all, both physically and spiritually, both in terms of their psychological and mental life. ${ }^{63}$

In the history of Islamic education it can be seen that Muslim educators in sharing different situations and conditions, have implemented and formulated various methods of education and teaching. Al-Ghazali for example, explained that the method of education that must be used by educators/teachers is the principle of "child centered" which is more concerned with students than educators themselves. Such methods can be realized in a variety of methods such as: examples of examples, guidance and counseling methods, story methods, motivation methods, reinforcement methods and so on.

For Ibn Khaldun, the method of approach in children's education is psychological one. The methodological principles he suggested were: (1) Not giving a difficult lesson to beginners, and students must be given gradual preparation that leads to perfection. (2) Giving lessons that are in accordance with the apprehension of students. (3) do not give knowledge that is beyond the ability of the students. ${ }^{64}$

The emotional (psychological) environment in the learning process also receives serious attention from Islamic education experts. The existence of a warm and familiar atmosphere becomes something that is necessary if you want the teaching and learning process to be optimal. Therefore AlGhazali requires the presence of a conducive,

${ }^{62}$ M. Quraish Shihab, "Membumikan" Al-Qur'an: fungsi dan peran wahyu dalam kehidupan masyarakat (Bandung: Mizan, 1995), p. 178.

63 Muhammad Qutb, Sistem Pendidikan Islam, trans. Salman Harun (Bandung, Indonesia:: Ma'arif, 1984), p. 27.

${ }^{64}$ Nizaruddin Wajdi and Muh Barid, "Pendidikan Ideal Menurut Ibnu Khaldun Dalam Muqaddimah," Jurnal Lentera: Kajian Keagamaan, Keilmuan Dan Teknologi Vol. 1, No. 2, 2015, pp. $272-283$. loving atmosphere by positioning educators as parents and students as their own children. ${ }^{65}$

Rasulullah Saw, in educating his Companions, he used more psychological approaches with this refinement, as expressed by Muawiyah:

... "for the sake of my father and mother, I have never and never seen a teacher, both before and after that were better than Muhammad in how to educate him. And by Allah he did not rebuke me, did not beat me, nor did he scorn me." (H.R. Muslim)

Physical education is also found in the concept of Islamic education which is formulated by many Islamic education experts. In the case of sports, Al-Ghazali for example, states: In the part of the daytime, the children should be accustomed to walking, moving the body, and practicing sports, so that they are not used to being lazy.

Regarding the game for Al-Ghazali, there is no obstacle to allowing children after leaving school to play well and how to play it politely, as well as the tools used according to their age. According to him, this is intended for the child to be able to rest sufficiently from the exhaustion of studying at school and also to entertain his heart after receiving lessons and brain spinning.

Physical education (ahdaf al-jismiyah) is intended to prepare human beings as the duty of the caliph's duty on earth, and this is done through physical exercises. The view that physical is important, presumably there is no difference between Islamic education and quantum learning. It's just that physical that is meant in quantum learning is physical, in the sense that it supports the learning process, this cannot be separated from the fact that quantum learning is an approach in the world of education, which has no ideological basis as well as Islamic education. His physiologically and psychologically in-depth studies of humans, may be an input that enriches the treasures of Islamic education to be more "grounded" again.

${ }^{65}$ Miska M. Amien, “Kerangka Epistemologi Al-Ghazali,” Jurnal Filsafat, Vol. 1, No. 1, 1993, pp. 11-19. 
In terms of learning methodology, a psychological approach in a warm and familiar atmosphere in quantum learning is essentially very relevant to Islamic teachings that want gentleness in the learning process (see Q.S. Âli 'Imran [3]: 159). But presumably related to learning methodology, Islamic education only has a concept that is less tested in the field. In the sense it is only more on the normative plain, which has not been pragmatically and empirically elaborated in the field.

Learning methods that have been formulated in the Quran such as: hiwâr method (dialogue), story method, analogy method (amtsâl), exemplary method, habituation method, method of advice, targhîb and tarhîb method, discussion method and lecture method, regardless of the substance discussed, are methods that are commonly used in almost every learning interaction. Presumably the breakthroughs in quantum learning that apply methods with global learning, the use of music that supports the learning process, the use of physical exercises to increase enthusiasm in the learning process, intense attention to emotional (psychological) students and other things from the learning methodology applied there, is a very valuable contribution to Islamic education.

\section{Conclusion}

Based on the study of quantum learning on his views on humans, the environment and learning methodology, which is then reviewed from the perspective of Islamic education, as explained above, there are several notes that can be put forward:

First, the success of quantum learning in its learning operations is inseparable from three things, namely its conception of humans as subjects and objects of education, learning environments and learning methodologies. All humans in the concept of quantum learning are considered to have the same potential to develop. Optimizing human potential is done by setting a supportive learning environment, both physical and emotional. The teaching methodology applied is touching all important aspects of the human person, both intellectually, physically and emotionally/personally, with the principle that learning is a lifelong activity that must and must be fun and successful. In quantum learning, any details will be considered as having suggestions that will support the learning process.

Second, in the perspective of Islamic education, the concept of quantum learning about humans (students), learning environment and learning methodology, in principle does not contradict, even gets the justification of the principles contained in Islamic education formulated in texts and opinions Islamic education experts. There are more differences in the discourse raised. In quantum learning, his comprehensive (holistic) view of humans, namely on reason, physical and mental (emotion) is aimed at optimizing human potential physiologically in the learning process. In Islamic Education, human discourse is integral and holistic, covering all aspects that are not only physical with the present and present context, but also include spiritual-transcendent and spiritual aspects. The learning methodology that is applied in quantum learning conceptually is no different from the methodology of Islamic education, that both approach psychologically, which touches the emotional side of students by arousing their enthusiasm for lifelong learning and a pleasant atmosphere. It's just that in quantum learning, the learning methodology has been practical, empirical and "free" in the sense that it is not bound by certain values, so that it is more flexible. Overall, then it can be said, that quantum learning with its conceptions of humans, learning environment and learning methodology applied there is a practical form that has been realized as an approach, from the principles contained in Islamic education that are still theoretical and philosophical.

\section{References}

Abidin, M. Zainal, "Islam Dan Ilmu Pengetahuan: Diskursus Pemikiran Muslim Kontemporer." ULUMUNA Vol. 10, No. 2, 2006.

Abidin, Muhammad Zainal, "Filsafat Ilmu-Ilmu Keislaman Integralistik: Studi Pemikiran Kuntowijoyo." Jurnal IImu Ushuluddin Vol. 13, No. 2, 2014. 
Amien, Miska M., "Kerangka Epistemologi AlGhazali." Jurnal Filsafat Vol. 1, No. 1, 1993.

An Nahlawi, Abdurrahman, Pendidikan Islam di Rumah, Sekolah dan Masyarakat. Gema Insani, 1995.

Barni, Mahyuddin, “Dasar Dan Tujuan Pendidikan Islam." Al-Banjari : Jurnal Ilmiah Ilmu-Ilmu Keislaman Vol. 7, No. 1, May 28, 2008, https:// doi.org/10.18592/al-banjari.v7i1.943, accessed May 7, 2018.

Bratasari, Rochmadani, “Eksperimen Pendekatan Quantum Teaching Dan Quantum Learning Terhadap Pemahaman Konsep Pada Anak Subnormal." Universitas Muhammadiyah Surakarta, 2009. http://eprints.ums.ac.id/4695, accessed July 6, 2018.

Darkasyi, Muhammad, Rahmah Johar, and Anizar Ahmad, "Peningkatan Kemampuan Komunikasi Matematis Dan Motivasi Siswa Dengan Pembelajaran Pendekatan Quantum Learning Pada Siswa SMP Negeri 5 Lhokseumawe." Jurnal Didaktik Matematika Vol. 1, No. 1, 2014.

DePorter, Bobbi, Quantum Memorizer: Remember Anything, Anytime. Oceanside, Calif.: Learning Forum Publications, 2007.

, Quantum Reading: The Power to Read Your Best. Oceanside, Calif.: Learning Forum Pub., 2000.

DePorter, Bobbi, and Mike Hernacki, Quantum Business: Achieving Success through Quantum Learning. New York: Dell, 1997.

Quantum Learning for Business: How to Be More Confident, Effective and Successful at Work. London: Piatkus, 1998.

, Quantum learning: membiasakan belajar nyaman dan menyenangkan. Translated by Alwiyah Abdurrahman. Bandung: Penerbit Kaifa, 1999.

, Quantum Learning: Unleash the Genius within You. London: Piatkus, 1993.

, Quantum Memory: Working Magic with Your Memory. Oceanside, Calif.: Learning Forum Publications, 2000.

, Quantum Notes: Whole-Brain Approaches to Note-Taking. Oceanside, Calif.: Learning Forum Publns, 2000.
, Quantum Pathways: Discovering Your Personal Learning Style. Oceanside, Calif.: Learning Forum Publications, 2000.

Quantum Thinking: Creative Thinking, Planning and Problem-Solving. Oceanside, Calif.: Learning Forum Publications, 2000.

, Quantum Writer: Write Easily, Less Stress, Better Results. Oceanside, Calif.: Learning Forum Publns, 2007.

, Quantum Writing: How to Write like a Pro. Oceanside, Calif.: Learning Forum Publications, 2000.

Douglass, Susan L., and Munir A. Shaikh, “Defining Islamic Education: Differentiation and Applications." Current Issues in Comparative Education Vol. 7, No. 1, December 15, 2004.

Fatah Yasin, Raudlotul Firdaus, and Mohd Shah Jani, "Islamic Education: The Philosophy, Aim, and Main Features." Conference presented at the International Conference on Psychology in Health, Educational, Social and Organization Settings, Surabaya, Indonesia, 2013. http://irep.iium.edu.my/34152/, accessed July 25, 2018.

Ghoni, Abdul, "Pemikiran Pendidikan Naquib AlAttas dalam Pendidikan Islam Kontemporer." Jurnal Lentera: Kajian Keagamaan, Keilmuan dan Teknologi Vol. 3, No. 1, March 30, 2017. Halstead, Mark, "An Islamic Concept of Education." Comparative Education Vol. 40, No. 4, November 1, 2004. https://doi.org/10.1080/030500604200 0284510, accessed July 10, 2018.

Hassan, Aminuddin, Asmawati Suhid, Norhasni Zainal Abiddin, Habsah Ismail, and Haziyah Hussin, "The Role of Islamic Philosophy of Education in Aspiring Holistic Learning." Procedia-Social and Behavioral Sciences, Vol. 5, 2010.

Lowther, Dianne, Introducing Neurolinguistic Programming for Work: A Practical Guide. New York: Icon Books, 2013.

Mastuhu, Memberdayakan sistem pendidikan Islam: strategi budaya menuju masyarakat akademik. Jakarta: Logos, 1999.

Muhajir, As'aril, “Tujuan Pendidikan Dalam Perspektif Al-Quran." Al-Tahrir Vol. 11, No. 2 November 1, 2011. 
Muhajir, Muhammad, "Model Pembelajaran Quantum Teaching Dalam Pembelajaran Pendidikan Agama Islam Di SDIT Buah Hati Sintang." Ulul Al Bab: Islamic Education Journal Vol. 1, No. 2, 2014.

Mujahidin, Anwar, and Zamzam Farrihatul Khoiriyah, "Konsep Pendidikan Prenatal Dalam Perspektif Tafsir Al-Mishbâh Karya M. Quraish Shihab." Ta'allum: Jurnal Pendidikan Islam Vol. 6, No. 1, June 1, 2018.

Musmualim, and Muhammad Miftah, "Pendidikan Islam di Keluarga Dalam Perspektif Demokrasi (Studi Pemikiran Hasan Langgulung dan Abdurrahman an Nahlawi)." JURNAL PENELITIAN Vol. 10, No. 2, December 29, 2016. https://doi. org/10.21043/jupe.v10i2.1781, accessed July 25, 2018.

Naqîb-al-'Attâs, Muhammad, The Concept of Education in Islam a Framework for an Islamic Philosophy of Education. Kuala Lumpur: International Institute of Islamic Thought and Civilization, 1999.

Qutb, Muhammad, Sistem Pendidikan Islam. Translated by Salman Harun. Bandung, Indonesia:: Ma'arif, 1984.

Rahman, Fazlur, Tema Pokok Al Quran. Translated by Anas Mahyuddin and Ammar Haryono. Bandung: Pustaka, 1996.

Rakhmat, Jalaluddin, Catatan Kang Jalal: Visi Media, Politik, dan Pendidikan. Bandung: Remaja Rosdakarya, 1997.

Rosidin, Dedeng. "Al-Tarbiyah Meaning in AlQuran and Its Implication in Learning and Commentary Education Major in Arabic FPBS UPI." EDUCARE Vol. 4, No. 1, 2011. http://www.journals.mindamas.com/index. php/educare/article/view/243, accessed July 10, 2018.

Salleh, Mohamad Johdi, "The Integrated Islamic Education: Principles and Needs for Thematic Approaches." In An Integrated Islamic Education: Need for Thematic Approaches, Singapore Islamic Education System (SIES) Seminar, Wisma MUIS, Singapore, On, Vol. 14, 2009.

Saqeb, Ghulam Nabi, "Some Reflections on Islamization of Education since 1977 Makkah
Conference: Accomplishments, Failures and Tasks Ahead." Intellectual Discourse Vol. 8, No. 1, June 1, 2000. https://doaj.org, accessed May 11, 2018.

Saryono, Saryono, "Konsep Fitrah dalam Perspektif Islam." Medina-Te : Jurnal Studi Islam Vol. 12, No. 2, 2016.

Schuster, Donald H, and Charles E Gritton, SALT: Suggestive Accelerative Learning Techniques : Theory and Applications. Ames, lowa: D. Schuster, 1985.

Schuster, Donald $\mathrm{H}$, and DesMoines, Society for Suggestive - Accelerative Learning and Teaching. Suggestive, Accelerative Learning and Teaching: A Manual of Classroom Procedures Based on the Lozanov Method. Charles Gritton, 1976.

Shihab, M. Quraish, "Membumikan” Al-Quran: fungsi dan peran wahyu dalam kehidupan masyarakat. Bandung: Mizan, 1995.

, Wawasan Al-Quran: Tafsir Tematik atas Pelbagai Persoalan Umat. Mizan Pustaka, 1996.

Singer-Nourie, Bobbi DePorter, Mark Reardon, Sarah, Quantum Teaching: Mempraktikkan Quantum Learning Di Ruang-Ruang Kelas. Kaifa, 2000.

Solichin, Mohammad Muchlis, "Fitrah: Konsep Dan Pengembangannya Dalam Pendidikan Islam." TADRIS: Jurnal Pendidikan Islam Vol. 2, No. 2, July 5, 2007. https://doi.org/10.19105/ jpi.v2i2.219, accessed July 6, 2018.

Suryani, Nunuk, “Improvement of Students' History Learning Competence through Quantum Learning Model at Senior High School in Karanganyar Regency, Solo, Central Java Province, Indonesia." Journal of Education and Practice Vol. 4, No. 14, 2013. Turnip, Jaidun, and Keysar Panjaitan, "Penerapan Model Quantum Learning Untuk Meningkatkan Hasil Belajar Autocad Teknik Gambar Bangunan." Jurnal Teknologi Pendidikan (JTP) Vol. 7, No. 2, 2014. http://jurnal.unimed. ac.id/2012/index.php/jtp/article/view/1856, accessed July 7, 2018.

Vella, Jane, "Quantum Learning: Teaching as Dialogue." New Directions for Adult and Continuing Education 2002, No. 93, 2002. 
Wajdi, Nizaruddin, and Muh Barid, "Pendidikan Ideal Menurut Ibnu Khaldun Dalam Muqaddimah." Jurnal Lentera: Kajian Keagamaan, Keilmuan Dan Teknologi Vol. 1, No. 2, 2015.
Widyastantyo, Hermawan, and others, "Penerapan Metode Quantum Learning Untuk Meningkatkan Hasil Belajar Mata Pelajaran IPA (SAINS) Bagi Siswa Kelas V SD Negeri Kebonsari Kabupaten Temanggung." Universitas Negeri Semarang, 2007. 